\title{
Testicular Perforation
}

National Cancer Institute

\section{Source}

National Cancer Institute. Testicular Perforation. NCI Thesaurus. Code C78637.

A rupture through the testicular tissue. 